\title{
Hybrid renewable energy photovoltaic and darrieus VAWT as propulsion fuel of prototype catamaran ship
}

\author{
Budhy Setiawan, Ekananda Sulistyo Putra, Indrazno Siradjuddin
}

Electrical Engineering Department, State Polytechnic of Malang, Malang, Indonesia

\begin{tabular}{l} 
Article Info \\
\hline Article history: \\
Received Dec 22, 2020 \\
Revised Mar 26, 2021 \\
Accepted Jun 19, 2021 \\
\hline Keywords: \\
Hybrid renewable energy \\
Photovoltaic module \\
Ship's propulsion \\
Wind turbine generator
\end{tabular}

Article Info

Wind turbine generator

\begin{abstract}
Currently, marine transportation in the world still uses fossil fuels. In addition to running low on supplies, fossil fuels also cause emissions that cause global warming. Sea transportation generates around 1,000 million tonnes of $\mathrm{CO}_{2}$ emissions. Therefore, the exploration of alternative energy is becoming a popular research direction. Several renewable energy sources include solar and wind energy. Indonesia has an average wind speed of above $8 \mathrm{~m} / \mathrm{s}$ at sea. Also, the energy potential of the sun is around $4.8 \mathrm{kWh} / \mathrm{m}^{2}$. Based on the potential of these renewable energy sources, this study discusses the potential of renewable energy sources from sunlight and wind, which are implemented in the prototype catamaran ship. The results obtained from the experiment, the total energy of photovoltaic (PV) and wind turbine generators is $774 \mathrm{Wh}$. This energy can be used to charge a battery with a battery specification of $35 \mathrm{Ah}$ for 6 hours.
\end{abstract}

This is an open access article under the CC BY-SA license.

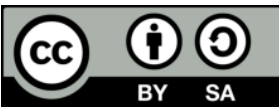

Corresponding Author:

Ekananda Sulistyo Putra

Electrical Engineering Department

State Polytechnic of Malang

Jl. Soekarno-Hatta No. 9, Malang 65141, Indonesia

Email: ekananda_putra@polinema.ac.id

\section{INTRODUCTION}

Currently, the majority of electrical energy is produced from fossils; almost $85 \%$ of all energy comes from fossil fuels [1], [2]. One of the sectors that use fossil fuels is sea transportation. More than 95\% of civil ships use diesel engines for propulsion [3]. Sea transport emissions around 1,000 million tonnes of $\mathrm{CO} 2$ yearly and contribute to $2.5 \%$ of global warming [4], [5]. Therefore, exploration of alternative energy, alternative fuels, energy conservation, and environmental protection technology is becoming a popular research direction [3], [6]-[8]. Renewable energy comes from natural resources such as sunlight, wind, tide and geothermal, which is replenished naturally [9]-[11].

The wind speed map based on the WindSat data, in Indonesia has wind speeds from $5 \mathrm{~m} / \mathrm{s}$ to $10 \mathrm{~m} / \mathrm{s}$ or greater than the minimum wind speed to drive wind turbine generator, which is $4 \mathrm{~m} / \mathrm{s}$ [2], [12]. Apart from wind energy, Indonesia has an average solar radiation potential around $4.8 \mathrm{kWh} / \mathrm{m}^{2} /$ day with a monthly variation of about $9 \%$ [13]. Wind turbines are alternative energy technologies that are able to convert wind energy into electrical energy [14], [15]. There are two types of wind turbines, namely horizontal-vertical axis wind turbine (HAWT) and vertical axis wind turbine (VAWT). The working principle of the HAWT wind turbine is based on the lift force of the wind energy while the VAWT wind turbine is based on the drag force that occurs due to wind movement [16], [17]. HAWT is widely used for higher production volumes that require a large investment and occupy more space for installation compared to VAWT [18], [19]. VAWT requires a low-cost investment and less space for installation compared to HAWT [16], [17]. Photovoltaic (PV) module is a semiconductor consisting of a dio [20] de p-n junction when exposed to sunlight, will create 
electrical energy that can be utilized, this energy conversion is called the photoelectric effect [5], [21]-[23]. Both renewable energy sources will be stored in lithium batteries [24], [25]. Using a lithium battery because it has the highest energy to weight and energy to space ratio of modern rechargeable batteries and is relatively light [26], [27].

In this research discusses the potential use of the that renewable energy sources which are implemented in the catamaran prototype with specifications length of arc $170 \mathrm{~cm}$, beam $100 \mathrm{~cm}$ and depth $32 \mathrm{~cm}$. Catamaran ship is a twin-hull ship [28], where the two hulls are connected with substantial deck construction and stretch on it to withstand large bending moments and shear forces and work towards the midline (Centerline) ship [29], [30]. The catamaran model uses a battery to supply energy to the DC motor. They were charging the battery using renewable energy sources of solar energy and wind turbine generators. 2 pieces of PV used with a specification of 100 wp per PV, while for wind turbines using the VAWT type.

\section{PROPOSED METHOD}

In this research, a catamaran ship model uses renewable energy to drive ship propulsion. The methodology used is collecting PV and wind turbine performance data using a microcontroller directly, simulating a controller to combine PV energy and wind turbines. Next, look at the power used by the motor and simulate the energy used by the ship.

\subsection{Energy system block diagram}

The block diagram system is shown in Figure 1. Wind energy will drive the wind turbine, which will drive the generator. The generator will produce $\mathrm{AC}$ voltage which is then rectified using a rectifier to produce DC voltage. The output voltage generated by the PV and generator in the wind turbine is connected to the buck-boost converter. Buck-boost converter is used to adjust the voltage so that the voltage is stable with a value of 14 Volts to charge the battery for driving power on the catamaran model. The specifications of the components used in this study are shown in Table 1 for wind turbine generator specifications, Table 2 for blade specifications, Table 3 for PV specifications, Table 4 for battery specifications and Table 5 for motor specification.

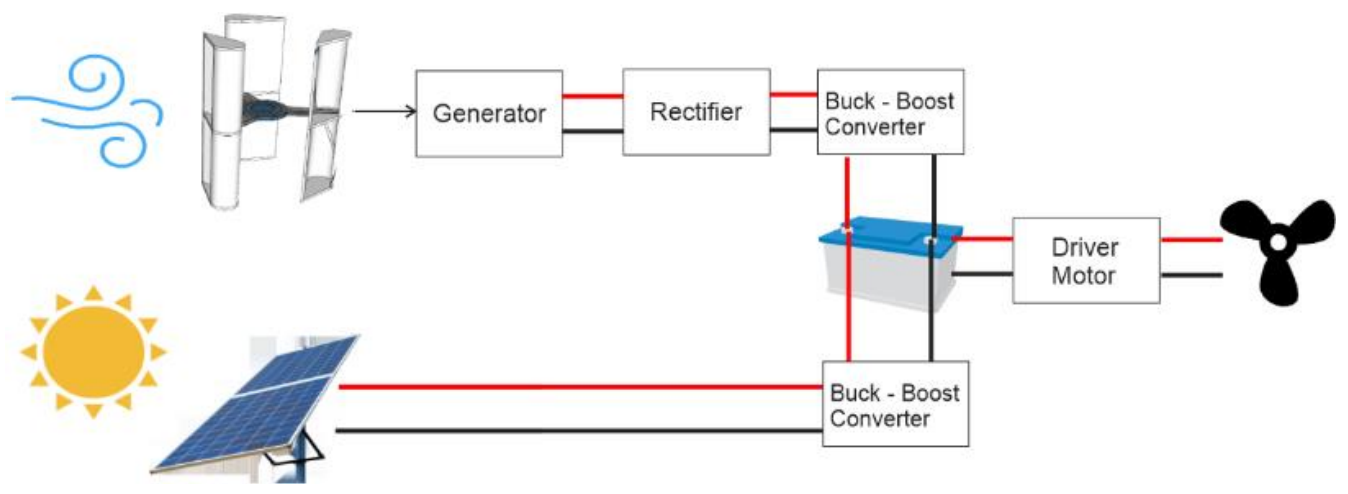

Figure 1. Energy system block diagram

Table 1. VAWT specification

\begin{tabular}{clc}
\hline No & Specification & Value \\
\hline 1 & Type & Darrieus VAWT \\
2 & Diameter & $120 \mathrm{~cm}$ \\
3 & Height & $200 \mathrm{~cm}$ \\
4 & Material & Alumunium Pipe \\
& & Stainless steel \\
& & Alumunium Dural \\
\hline
\end{tabular}

Table 3. Photovoltaic module specification

\begin{tabular}{clc}
\hline No & \multicolumn{1}{c}{ Specification } & Value \\
\hline 1 & Max Power & 100 Watt \\
2 & Open Circuit Voltage & 19.2 Volt \\
3 & Short Circuit Current & 6.87 Ampere \\
4 & Max Power Voltage & 16 Volt \\
5 & Max Power Current & 6.25 Ampere \\
\hline
\end{tabular}

Hybrid renewable energy photovoltaic and darrieus VAWT as propulsion fuel of ... (Budhy Setiawan)
Table 2. Blade specification

\begin{tabular}{clc}
\hline No & Specification & Value \\
\hline 1 & Type & 0015 \\
2 & Blade Amount & 3 \\
3 & Material & Balsa Wood \\
4 & Height & $150 \mathrm{~cm}$ \\
5 & Length & $16 \mathrm{~cm}$ \\
6 & Width & $1.9 \mathrm{~cm}$ \\
\hline
\end{tabular}

Table 4. Battery specification

\begin{tabular}{clc}
\hline No & Specification & Value \\
\hline 1 & Capacity & $35 \mathrm{Ah}$ \\
2 & Voltage & $12.8 \mathrm{Volt}$ \\
3 & Weight & $3.8 \mathrm{Kg}$ \\
4 & Dimension & $348 \mathrm{~mm} \times 261 \mathrm{~mm} \times 30 \mathrm{~mm}$ \\
\hline
\end{tabular}


Table 5. Motor specification

\begin{tabular}{clc}
\hline No & Specification & Value \\
\hline 1 & Voltage & $12 \mathrm{Volt}$ \\
2 & KV Value & $460 \mathrm{KV}$ \\
3 & Speed & $5300 \mathrm{rpm}$ \\
4 & Diameter & $90 \mathrm{~mm}$ \\
5 & Type & Submerge BLDC Motor \\
\hline
\end{tabular}

\subsection{Hardware design}

Figure 2 is the electronics components used in the research. Three current and voltage sensors are used to determine the energy of PV, wind turbine, and accumulator. The wind direction sensor and wind sensor are used to determine wind direction and determine wind speed in real-time, respectively. Optocoupler is used to determine the RPM of wind turbines. The RF transmitter is used to send the data that has been obtained by microcontroller to the ground station. Figure 3 is a design of a catamaran ship prototype with LoA specifications $170 \mathrm{~cm}$, beam $100 \mathrm{~cm}$, and depth $32 \mathrm{~cm}$.

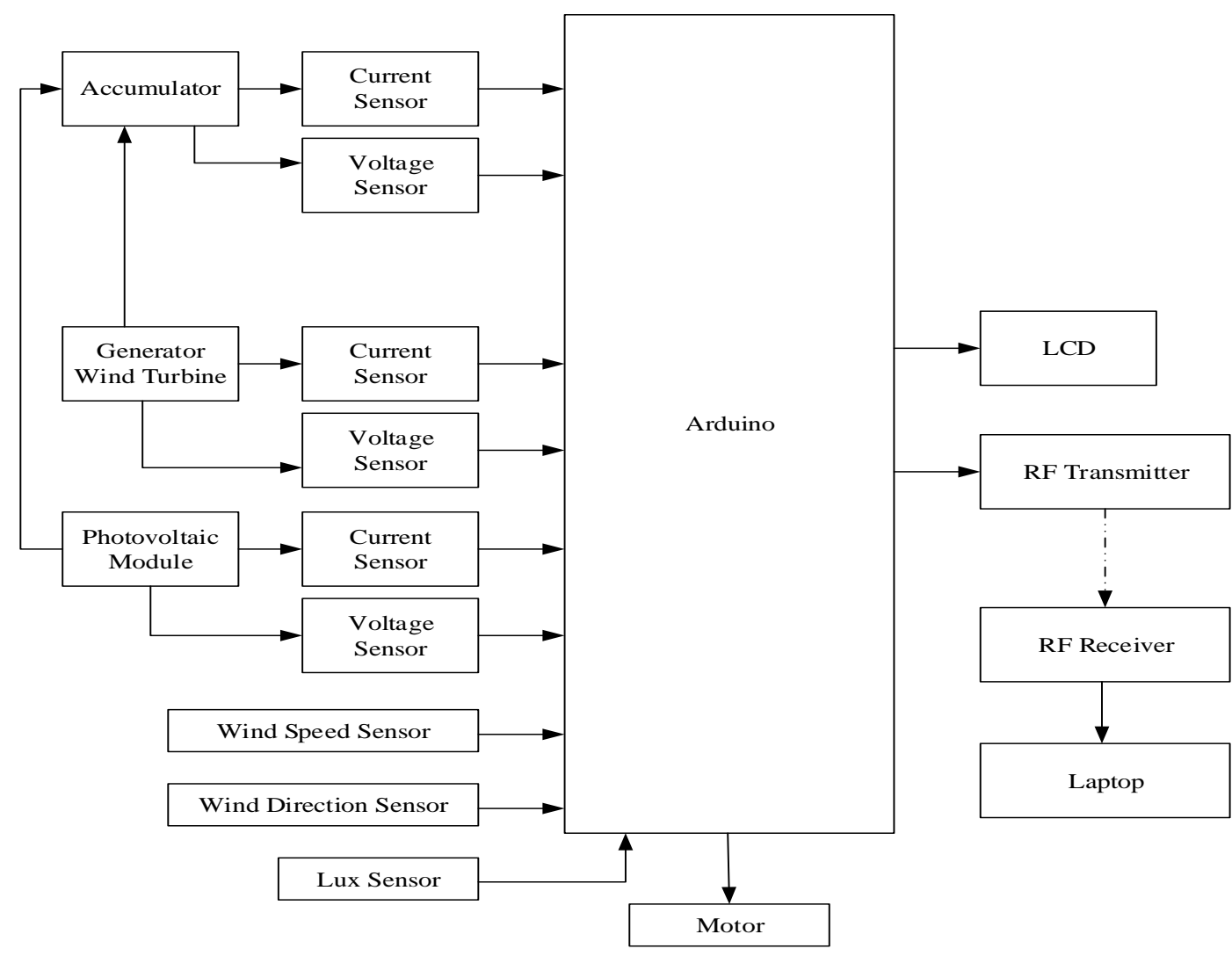

Figure 2. Electronics data acquisition design

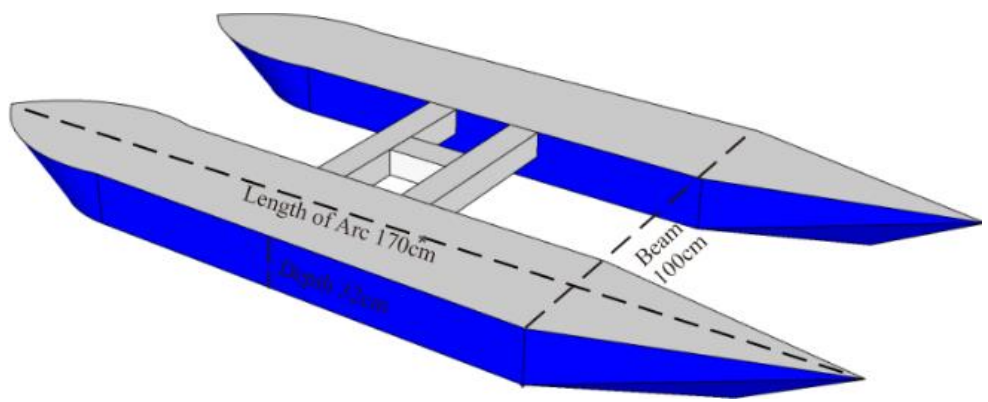

Figure 3. Ship mechanical design 
The planned draft is about $15 \mathrm{~cm}$, so that the ship's deadweight tonnage value is around $85 \mathrm{~kg}$. Deadweight tonnage means the total weight of the ship (mechanical weight and payload) that can be transported by the ship. The prototype of this ship is made using fiber and resin with a maximum weight of prototype catamaran ship is $17 \mathrm{Kg}$, using 2 BLDC motors with the specifications in Table 5.

\section{RESULTS AND DISCUSSION}

\subsection{Result of wind speed identification}

Identification of wind speed using a data logger for 3 days. Then these results will be calculated the average per hour. It was found that the lowest wind speed is around $0.4 \mathrm{~m} / \mathrm{s}$ and the highest wind speed is around $4.65 \mathrm{~m} / \mathrm{s}$. So that the average wind speed is about $2.71 \mathrm{~m} / \mathrm{s}$. The graph of the wind speed is shown in Figure 4.

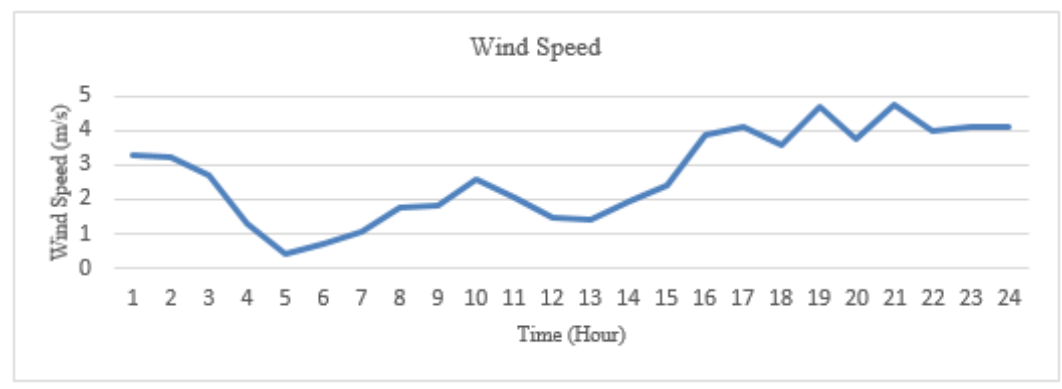

Figure 4. Wind speed

From the experimental results obtained, the maximum power that can be generated by the wind turbine generator is 39 watts, which is when the wind speed is around $4.6 \mathrm{~m} / \mathrm{s}$. The energy produced was about $354 \mathrm{Wh}$ for one day of the experiment. The graph of the power generated by the wind turbine generator is described in Figure 5.

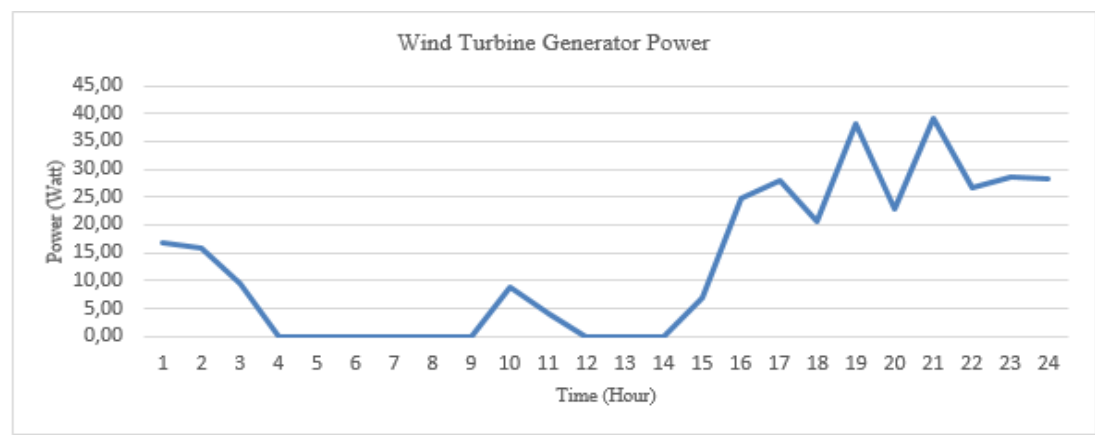

Figure 5. Wind turbine generator power

\subsection{Results of photovoltaic identification}

PV module performance identification was carried out for three days, from 09.00 to 15.50 hours. In this measurement using 2 PV installed in parallel, the load used is a lithium battery, voltage and current data will be saved to the data logger using a microcontroller as shown in Figure 6.

From the results of the PV performance test, it is described in Figure 7, which shows the lux value in the time range from 08.56 to 15.50 hours. The highest lux value was obtained at $11: 15$, which is around 110,000 lux and the average lux value at the time of testing was approximately 66,365 lux. Based on Figure 8 shows the value of power against time. The highest power is obtained around 75 Watts. Meanwhile, the average power during the testing period is around 60.07 Watt. From the experiments, the PV power used is $200 \mathrm{Wp}$, while the results of the PV test can produce $420 \mathrm{Wh}$. 


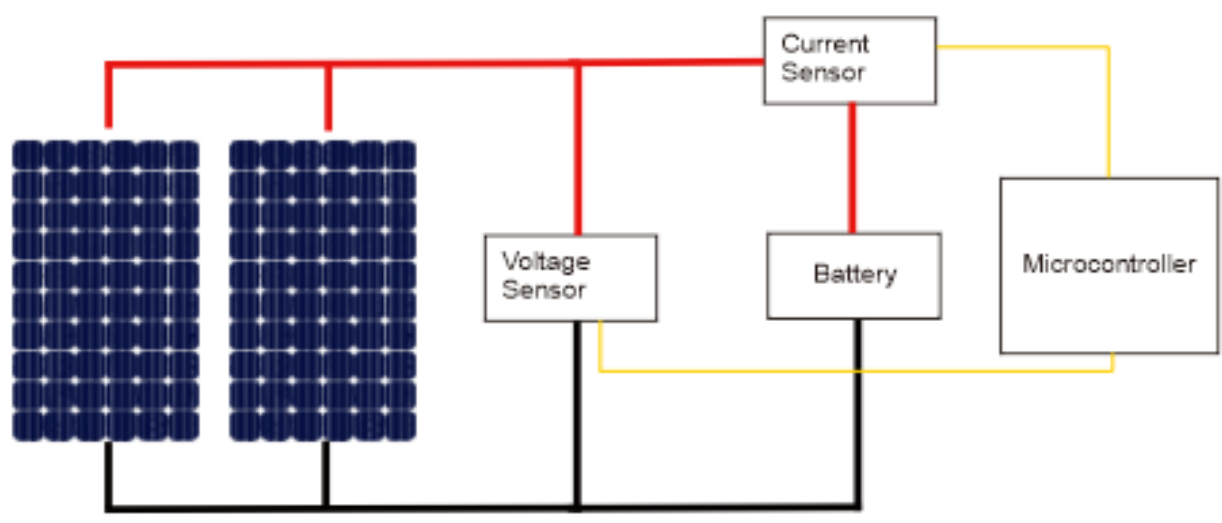

Figure 6. Battery charging by PV

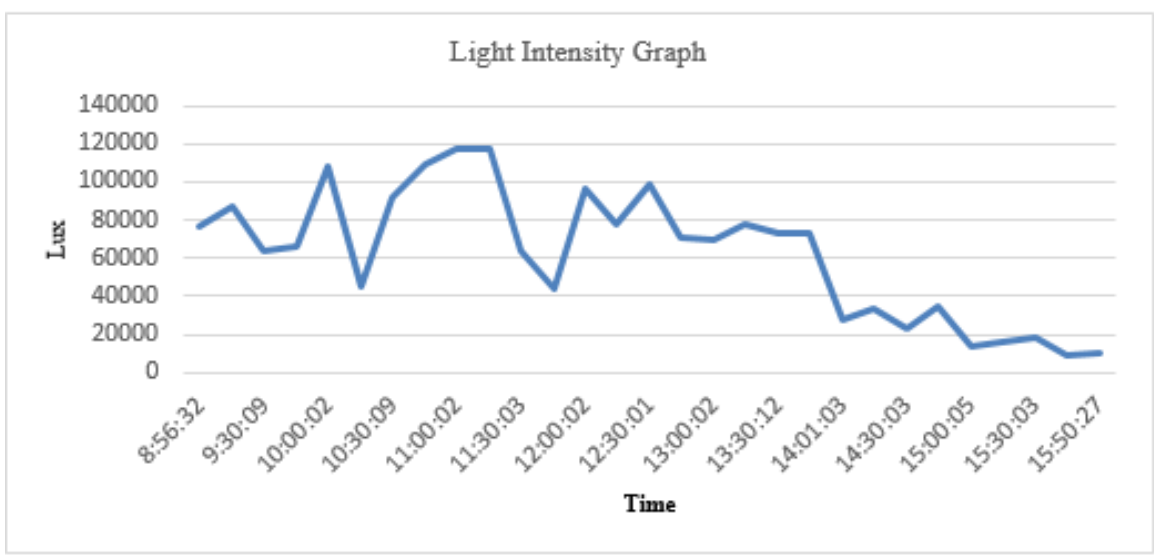

Figure 7. Day light itensity

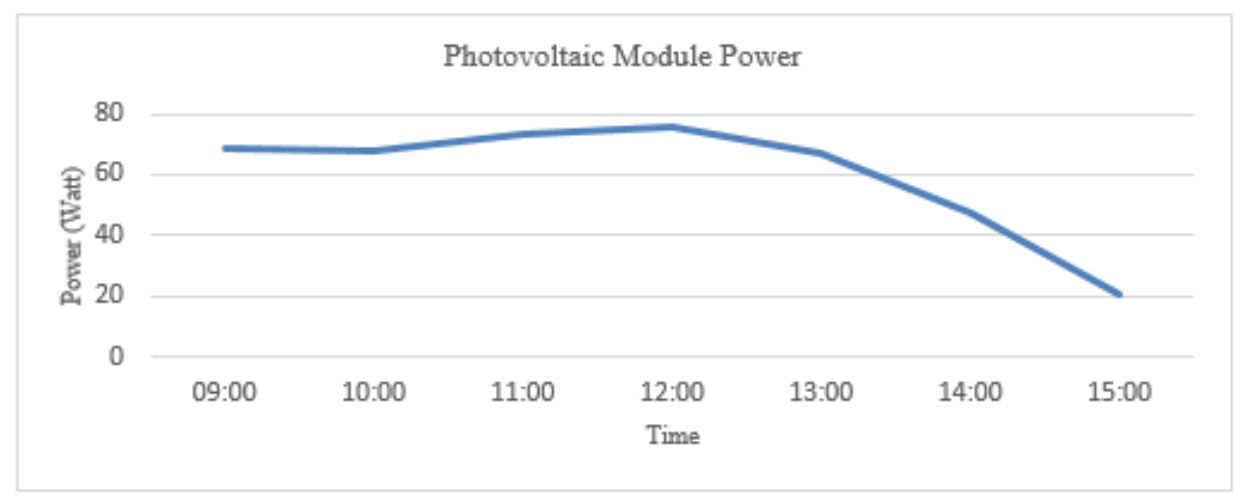

Figure 8. Photovoltaic module power

\subsection{Propeler motor identification}

From the motor, testing is done by tying the ship model and changing the throttle value on the remote. Next, observe the current required by the motor and the thrust that produced by the motor. The results obtained are shown in the Table 6 and Figure 9. 
Table 6. BLDC motor test results

\begin{tabular}{ccccc}
\hline Throtle (\%) & Voltage (Volt) & Current (A) & Thrust (Kg) & Power (Watt) \\
\hline 10 & 12.7 & 2.2 & 3.4 & 27.94 \\
25 & 12.8 & 5.1 & 5.1 & 65.28 \\
50 & 12.7 & 10 & 7 & 127 \\
75 & 12.6 & 20.4 & 13 & 257.04 \\
100 & 12.4 & 38 & 18 & 474 \\
\hline
\end{tabular}

Based on Figure 9, the value of motor power to changes in the value of the throttle on the remote. From the experiments that have been carried out, the maximum power value is $474 \mathrm{Watt}$. The next test is the thrust motor. The results obtained are described in the Figure 10.

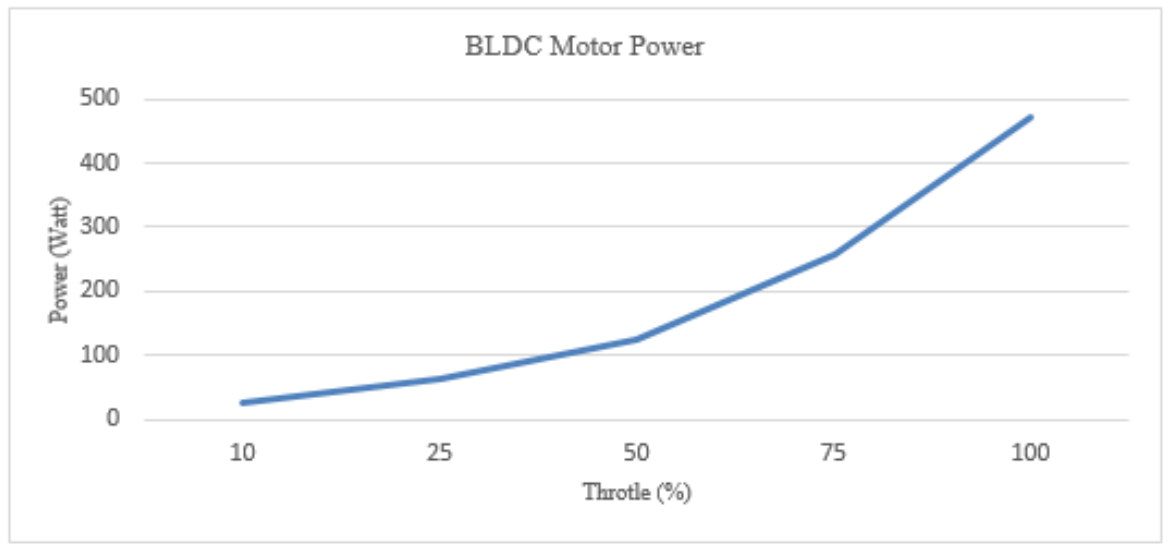

Figure 9. BLDC motor power

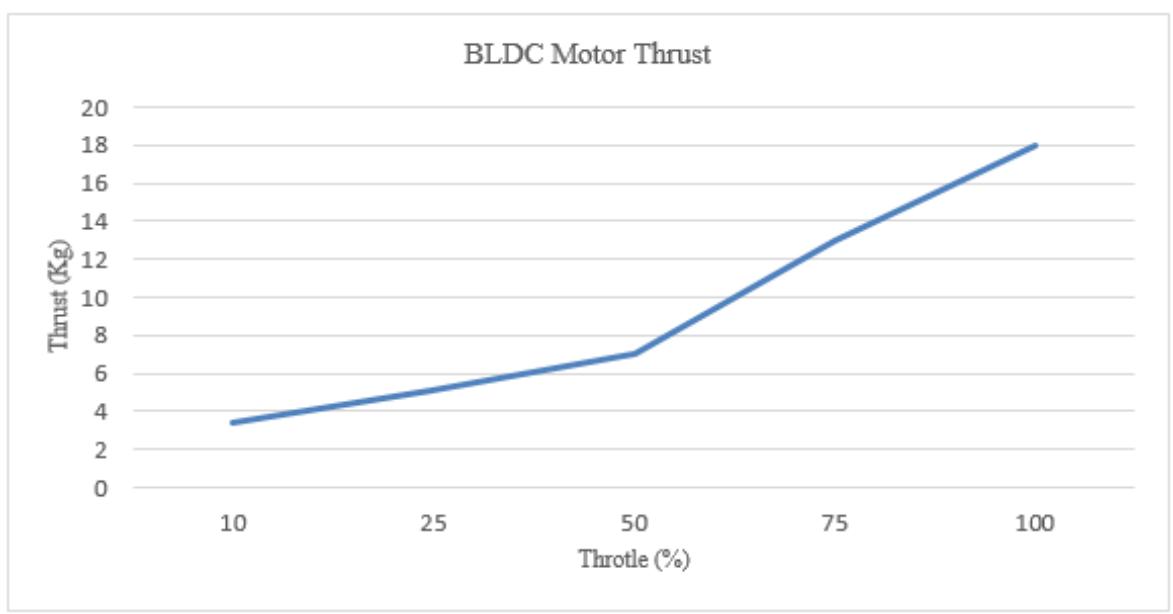

Figure 10. BLDC motor thrust

Based on Figure 10, the value of motor thrust to changes in the value of the throttle on the remote. From the experiments that have been done, the maximum power value is $18 \mathrm{Kg}$ which is shown in Figure 11. From the graph above shows the ship speed when the load changes are given. The maximum speed of the ship with weight payload $3 \mathrm{Kg}$ is $1.81 \mathrm{~m} / \mathrm{s}$ (3.5 Knots). With weight payload $10 \mathrm{~kg}$, the ship speed is $1.3 \mathrm{~m} / \mathrm{s}$ (2.57 Knots). At a payload of $15 \mathrm{~kg}$, the ship speed is $1.07 \mathrm{~m} / \mathrm{s}(2.07 \mathrm{Knots})$. 


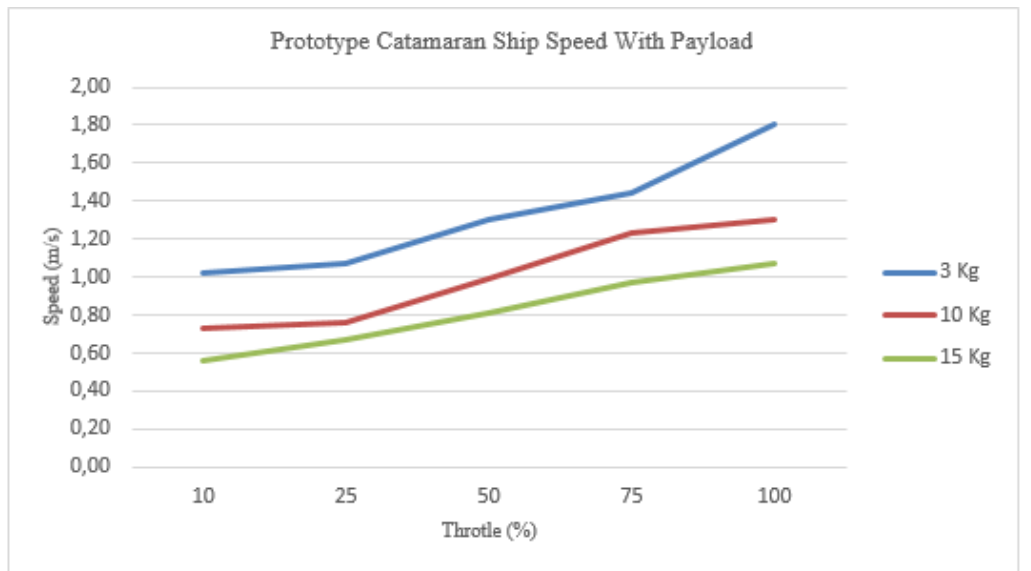

Figure 11. Prototype catamaran ship speed with payload

\subsection{Energy simulation}

From the experiments conducted, it is obtained the PV power and wind turbine generator power which is described in Figure 12. The battery has a capacity of 35Ah and $100 \%$ DoD. Which shows that the battery is capable of producing a current of 35 Amperes continuously within 1 hour. From the identification results of PV, wind turbine, and motor parameters obtained as shown in the Table 7.

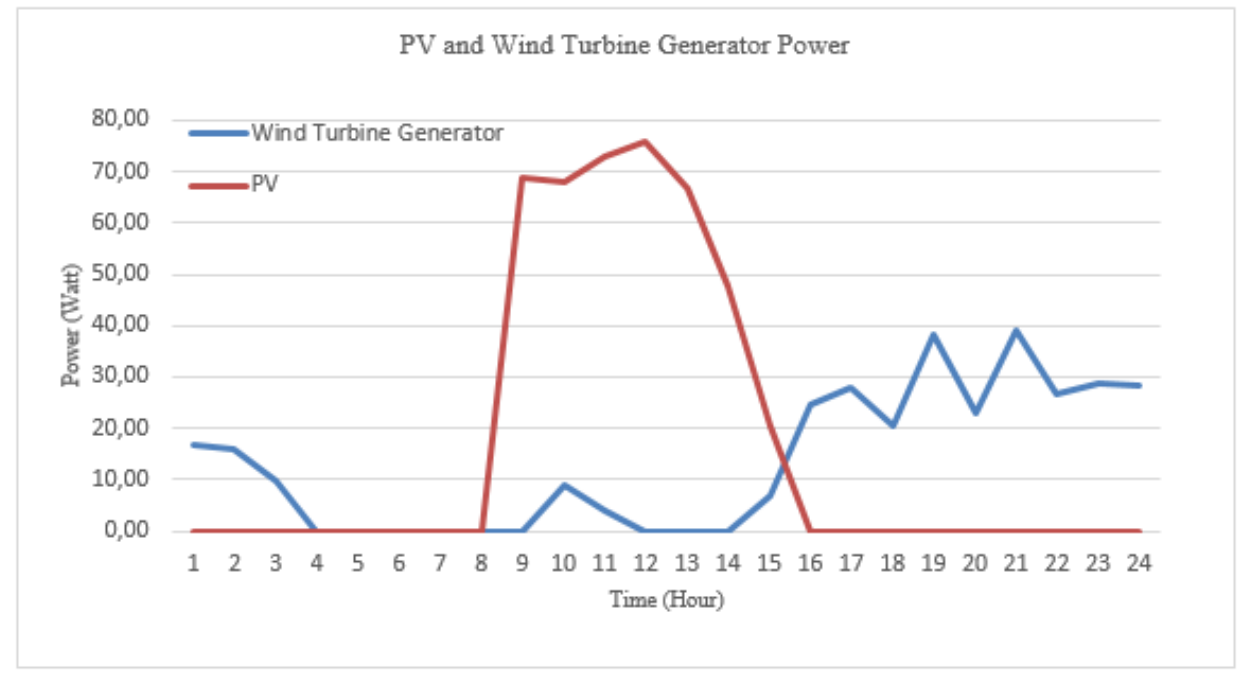

Figure 12. PV and wind turbine power generation

Table 7. Energy and power parameters

\begin{tabular}{clc}
\hline No & \multicolumn{1}{c}{ Parameters } & Value \\
\hline 1 & PV Energy & $420 \mathrm{Wh}$ \\
2 & Wind Turbine Generator Energy & $354 \mathrm{Wh}$ \\
3 & Motor Power & $474 \mathrm{~W}$ \\
4 & Battery Energy & $448 \mathrm{Wh}$ \\
\hline
\end{tabular}

From Table 7, it is found that the battery time can work when the motor is used as shown in (1)-(3):

$$
\begin{aligned}
& I_{\text {motor }}=\frac{P_{\text {motor }}}{V} \\
& I_{\text {motor }}=\frac{474 \mathrm{Watt}}{12.8 \mathrm{Volt}}=37 \text { Ampere }
\end{aligned}
$$




$$
\text { Time }=\frac{35 \mathrm{Ah}}{37 \mathrm{Ah}}=0.945 \text { Hour }=56,7 \text { Minutes }
$$

From the above calculations, it is obtained, that the value of the battery discharge time, when used maximum PWM for 56.7 minutes. Furthermore, for the measure of the battery charging time. PV energy is obtained during the 7-hour test, so the average power that can be generated is 60 Watts. At the same time, wind turbine energy is obtained from the test results for 24 hours so that the power produced is 14.75 Watt. The total power generated by the system is 74.75 watts.

$$
\begin{aligned}
& P_{\text {total }}=P_{p v}+P_{\text {wind turbine generator }} \\
& I=\frac{P_{\text {total }}}{V} \\
& I=\frac{74.75}{12.8}=5.8 \text { Ampere } \\
& \text { Time }=\frac{35 \mathrm{Ah}}{5.8 \mathrm{Ah}}=6 \mathrm{Hour}
\end{aligned}
$$

Then it takes about 6 hours to charge the battery fully.

\section{CONCLUSION}

In this study, the main objective is to see the ability to use solar and wind as the main energy of the catamaran prototype that has been made with a Maximum total weight is $34 \mathrm{Kg}$ with details $15.2 \mathrm{Kg}$ for mechanical of prototype, $15 \mathrm{Kg}$ for payload, and $3.8 \mathrm{Kg}$ for battery. From the experiment results, the total energy of PV and wind turbine generators is $774 \mathrm{Wh}$. This energy can be used to charge a battery with a battery specification of 35Ah for 6 hours. Meanwhile, when the battery is full, it can supply the motor with a power of 474 Watt for 56.7 minutes at a speed of $1.81 \mathrm{~m} / \mathrm{s}$ ( 3.5 Knots) when the payload weight is $3 \mathrm{~kg}$ and when the payload is $15 \mathrm{~kg}$, the ship speed is about $1.07 \mathrm{~m} / \mathrm{s}(2.07 \mathrm{Knots})$.

\section{APPENDIX}

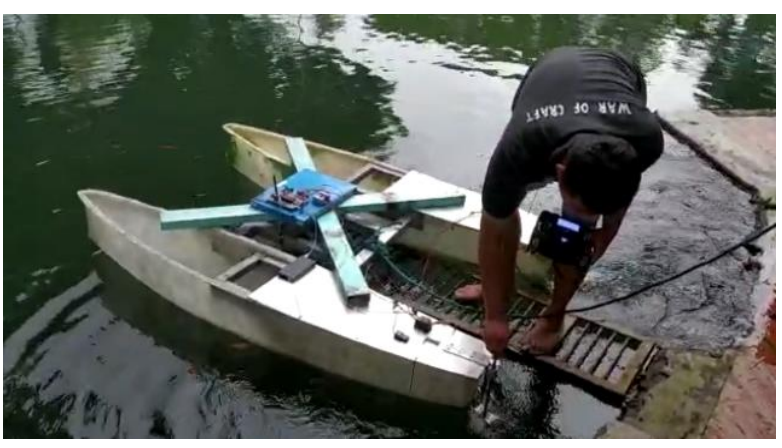

Prototype catamaran ship testing

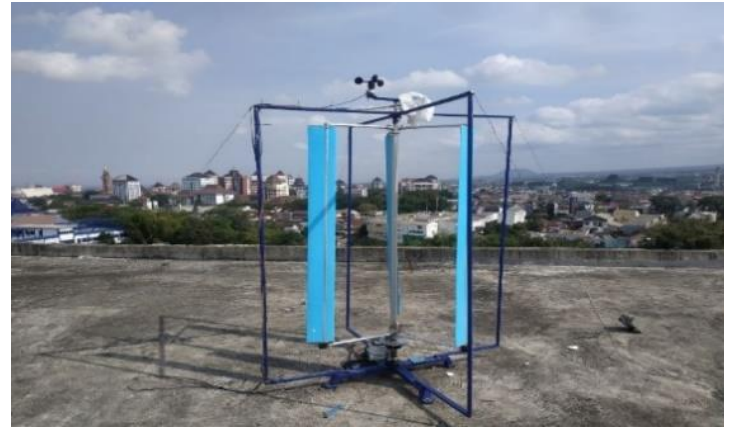

Darrieus VAWT

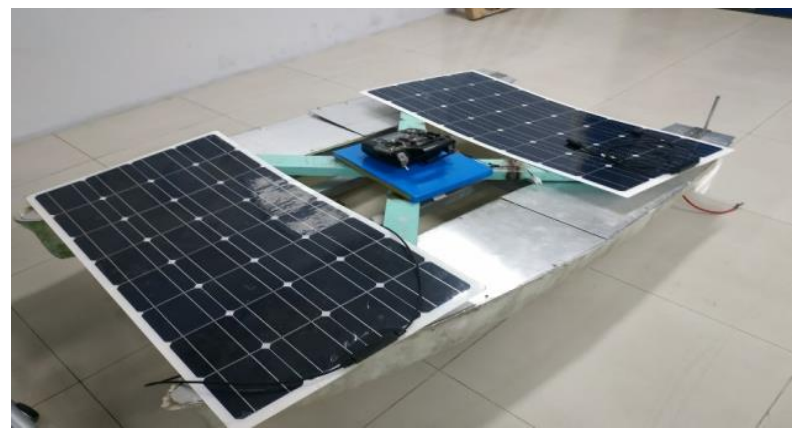

Machanical prototype catamaran ship with PV 


\section{REFERENCES}

[1] B. Setiawan, F. Ronilaya, D. K. P. Aji, A. Setiawan, and E. S. Putra, "Online monitoring and data logging power quality parameters of Low Voltage Distribution Panel (LVDP) on industrial system," in IOP Conference Series Materials Science and Engineering, Bandung, Indonesia, 2019, vol. 830, no. 3, p. 032032, doi: 10.1088/1757899X/830/3/032032.

[2] S. Rehman, M. M. Alam, L. M. Alhems, and M. M. Rafique, "Horizontal Axis Wind Turbine Blade Design Methodologies for Efficiency Enhancement - A Review," Energies, vol. 11, no. 3, pp. 1-34, 2018, doi: 10.3390/en11030506.

[3] Y. Yuan, J. Wang, X. P. Yan, T. Long, and B. Shen, "A review of multi-energy hybrid power system for ships," Renewable and Sustainable Energy Reviews, vol. 132, p. 110081, 2020, doi: 10.1016/j.rser.2020.110081.

[4] M. Krcum, A. Gudelj, and V. Tomas, "Optimal Design of Ship's Hybrid Power System for Efficient Energy," Transaction on Maritime Science, vol. 7, no. 1, pp. 23-32, 2018, doi: 10.7225/toms.v07.n01.002.

[5] M. R. Banaei and R. Alizadeh, "Simulation-Based Modeling and Power Management of All-Electric Ships Based on Renewable Energy Generation Using Model Predictive Control Strategy," in IEEE Intelligent Transportation Systems Magazine, vol. 8, no. 2, pp. 90-103, Summer 2016, doi: 10.1109/MITS.2016.2533960.

[6] I. Sofimieari, M. W. B. Mustafa, and F. Obite, "Modelling and analysis of a PV/wind/diesel hybrid standalone microgrid for rural electrification in Nigeria," Bulletin of Electrical Engineering and Informatics, vol. 8, no. 4, pp. 1468-1477, 2019, doi: 10.11591/eei.v8i4.1608.

[7] Y. Sun, X. Yan, C. Yuan, X. Tang, R. Maleklan, C. Guo, and Z. Li, "The application of hybrid photovoltaic system on the ocean-going ship:engineering practice and experimental research," Journal of Marine Engineering Technology, vol. 18, no. 2, pp. 1-11, 2019, doi: 10.1080/20464177.2018.1493025.

[8] M. Gaber, S. H. El-banna, M. S. Hamad and M. Eldabah, "Performance Enhancement of Ship Hybrid Power System Using Photovoltaic Arrays," 2020 IEEE PES/IAS PowerAfrica, 2020, pp. 1-5, doi: 10.1109/PowerAfrica49420.2020.9219808.

[9] B. Jaganathan, D. Sattinadan, and S. Vidyasagar, "Minimum-Order Observers for hybrid Wind Turbine and Fuel Cell," Bulletin of Electrical Engineering and Informatics, vol. 1, no. 2, pp. 151-164, 2012, doi: 10.11591/eei.v1i2.245.

[10] M. Lamnadi, M. Trihi, and A. Boulezhar, "Study of a hybrid renewable energy system for a rural school in Tagzirt, Morocco," 2016 International Renewable and Sustainable Energy Conference (IRSEC), 2016, pp. 381-386, doi: 10.1109/IRSEC.2016.7984079.

[11] H. A. Gabbar and M. R. Abdussami, "Feasibility Analysis of Grid-Connected Nuclear-Renewable Micro Hybrid Energy System," 2019 IEEE 7th International Conference on Smart Energy Grid Engineering (SEGE), 2019, pp. 294-298, doi: 10.1109/SEGE.2019.8859925.

[12] B. Setiawan, E. S. Putra, I. Siradjuddin, and M. Junus, "Optimisation solar and wind hybrid energy for model catamaran ship," IOP Conference Series: Materials Science and Engineering, vol. 1073, no. 1, p. 012044, 2021, doi: https://doi.org/10.1088/1757-899X/1073/1/012044.

[13] N. A. Handayani and D. Ariyanti, "Potency of Solar Energy Applications in Indonesia," International Journal of Renewable Energy Development, vol. 1, no. 2, pp. 33-38, 2012, doi: https://doi.org/10.14710/ijred.1.2.33-38.

[14] C. Promdee and C. Photong, "Effects of Wind Angles and Wind Speeds on Voltage Generation of Savonius Wind Turbine with Double Wind Tunnels," Procedia Computer Science, vol. 86, pp. 401-404, 2016, doi: 10.1016/j.procs.2016.05.044.

[15] B. Setiawan, I. I. Habibi, A. Parastiwi, A. M. Damayanti, and R. N. Wakidah, "Dynamic VAWT Darrieus by changing angle of attack to reach maximum efficiency," IOP Conference Series: Materials Science and Engineering, vol. 732, p. 012058, 2020., doi: https://doi.org/10.1088/1757-899X/732/1/012058.

[16] L. Nguyen and M. Metzger, "Optimization of a vertical axis wind turbine for application in an urban/suburban area," Journal of Renewable and Sustainable Energy, vol. 9, no. 4, p. 043302, 2017, doi: https://doi.org/10.1063/1.4994574.

[17] C. Vivek, P. Gopikrishnan, R. Murugesh, and R. R. Mohamed, "A Review on Vertical and Horizontal Axis Wind Turbine," International Research Journal of Engineering and Technology (IRJET), vol. 4, no. 4, pp. 247-250, 2017.

[18] L. Gumilar, A. Kusumawardana, D. Prihanto, and H. Wicaksono, "Analysis Performance Vertical Axis Wind Turbine Based on Pitch Angle to Output Power," 2019 International Conference on Information and Communications Technology (ICOIACT), 2019, pp. 767-772, doi: 10.1109/ICOIACT46704.2019.8938519.

[19] M. O. KORUKCU, "Numerical Investigation of Vertical Axis Wind Turbine for Different Parameters," 2019 4th International Conference on Smart and Sustainable Technologies (SpliTech), 2019, pp. 1-5, doi: 10.23919/SpliTech.2019.8783100.

[20] Wang Haiying, Wu Feng, Fu Ying, Li Ran and Zhang Qian, "Study on key technologies of lithium battery for electric vehicle," Proceedings of 2011 6th International Forum on Strategic Technology, 2011, pp. 291-294, doi: 10.1109/IFOST.2011.6021025.

[21] N. S. Hussin et al., "Performance Factors of the Photovoltaic System: A Review," MATEC Web of Conferences, vol. 225, p. 03020, 2018, doi: 10.1051/matecconf/201822503020.

[22] N. Rawat, P. Thakur, and U. Jadli, "Solar PV parameter estimation using multi-objective optimisation," Bulletin of Electrical Engineering and Informatics, vol. 8, no. 4, pp. 1198-1205, 2019, doi: 10.11591/eei.v8i4.1312.

[23] B. G. Bhang, W. Lee, G. G. Kim, J. H. Choi, S. Y. Park, and H. -K. Ahn, "Power Performance of Bifacial c-Si PV Modules With Different Shading Ratios," in IEEE Journal of Photovoltaics, vol. 9, no. 5, pp. 1413-1420, Sept. 2019, doi: 10.1109/JPHOTOV.2019.2928461. 
[24] H. Zhao, Q. Wu, S. Hu, H. Xu, and C. N. Rasmussen, "Review of energy storage system for wind power integration support," Applied Energy, pp. 545-553, 2015, doi: 10.1016/j.apenergy.2014.04.103.

[25] C. Yao, M. Chen, and Y. Hong, "Novel Adaptive Multi-Clustering Algorithm-Based Optimal ESS Sizing in Ship Power System Considering Uncertainty," in IEEE Transactions on Power Systems, vol. 33, no. 1, pp. 307-316, Jan. 2018, doi: 10.1109/TPWRS.2017.2695339.

[26] H. Keshan, J. Thornburg, and T. S. Ustun, "Comparison of lead-acid and lithium ion batteries for stationary storage in off-grid energy systems," 4th IET Clean Energy and Technology Conference (CEAT 2016), 2016, pp. 1-7, doi: 10.1049/cp.2016.1287.

[27] C. Iclodean, B. Varga, N. Burnete, D. Cimerdean, and B. Jurchiş, "Comparison of Different Battery Types for Electric Vehicles," IOP Conference Series: Materials Science and Engineering, vol. 252, p. 012058, 2017, doi: $10.1088 / 1757-899 X / 252 / 1 / 012058$

.228] Y. Yanuar et al., "Numerical and Experimental Analysis of Total Hull Resistance on Floating Catamaran Pontoon for N219 Seaplanes based on Biomimetics Design with Clearance Configuration," International Journal of Technology, vol. 11, no. 7, p. 1397, 2020, doi: https://doi.org/10.14716/ijtech.v11i7.4503.

[29] M. Iqbal and S. Samuel, "Traditional Catamaran Hull Form Configurations that Reduce Total Resistance," International Journal of Technology, vol. 8, no. 1, p. 85, 2017.

[30] A. Kurniawan, Hardianto, E. S. Koenhardono and I. R. Kusuma, "Modeling and control of ballast system to improve stability of catamaran boat," 2015 International Conference on Advanced Mechatronics, Intelligent Manufacture, and Industrial Automation (ICAMIMIA), 2015, pp. 202-204, doi: 10.1109/ICAMIMIA.2015.7508032. 